\title{
Working conditions of Nursing professionals in coping with the Covid-19 pandemic
}

\author{
Condições de trabalho dos profissionais de enfermagem \\ no enfrentamento da pandemia da Covid-19 \\ Condiciones de trabajo de los profesionales de enfermería \\ para afrontar la pandemia del Covid-19 \\ Marli Terezinha Stein Backes ${ }^{a}$ \\ Giovana Dorneles Callegaro Higashi ${ }^{\mathbf{b}}$ \\ Pattrícia da Rosa Damiania \\ Janifer Souza Mendes ${ }^{a}$ \\ Lucimar de Souza Sampaio ${ }^{a}$ \\ Gustavo Lopes Soares ${ }^{a}$
}

\begin{abstract}
How to cite this article: Backes MTS, Higashi GDC, Damiani PR, Mendes IS, Sampaio LS, Soares GL. Working conditions of the Nursing professionals in coping with the Covid-19 pandemic. Rev Gaúcha Enferm. 2021;42(spe):e20200339 doi: https://doi.org/10.1590/19831447.2021.20200339
\end{abstract}

aniversidade Federal de Santa Catarina (UFSC). Florianópolis, Santa Catarina, Brasil.

Universidade Federal de Santa Maria (UFSM). Sant Maria, Rio Grande do Sul, Brasil.

\section{ABSTRACT}

Objective: To trigger a reflection on the current working conditions of Nursing professionals in coping with the Covid-19 pandemic. Method: A theoretical-reflective study supported by studies from the Marxist perspective, national and international scientific articles, and official documents from the World Health Organization and the Federal Nursing Council.

Results: The daily work of Nursing professionals in the face of the Covid-19 pandemic presents unfavorable working conditions in Brazil and worldwide, with emphasis on the deficit of professionals, overload of activities, low pay, and personal protective equipment, often insufficient and inadequate, conditions that can lead to exhaustion, illness and death.

Conclusion: This study can contribute to raising discussions about the need for improvements in the working conditions of Nursing professionals, especially in pandemic times and the impact on the health of these professionals.

Keywords: Working conditions. Psychosocial impact. Coronavirus infections. Nurse practitioners.

\section{RESUMO}

Objetivo: Desencadear uma reflexão sobre as atuais condições de trabalho dos profissionais de enfermagem no enfrentamento da pandemia da Covid-19.

Método: Estudo teórico-reflexivo sustentado por estudos da vertente marxista, artigos científicos nacionais e internacionais e por documentos oficiais da Organização Mundial da Saúde e do Conselho Federal de Enfermagem.

Resultados: 0 cotidiano laboral dos profissionais de enfermagem diante da pandemia da Covid-19 apresenta condições de trabalho desfavoráveis no Brasil e no mundo todo, com destaque para o déficit de profissionais, sobrecarga de atividades, baixa remuneração e equipamentos de proteção individual, muitas vezes, insuficientes e inadequados, condições essas que podem levar à exaustão, ao adoecimento e à morte.

Conclusão: Este estudo pode contribuir para suscitar discussões sobre a necessidade de melhorias nas condiç̧̃es de trabalho dos profissionais de enfermagem, especialmente, em tempos de pandemia e o impacto na saúde destes profissionais.

Palavras-chave: Condições de trabalho. Impacto psicossocial. Infecções por coronavírus. Profissionais de enfermagem.

\section{RESUMEN}

Objetivo: Elaborar una reflexión sobre las condiciones laborales actuales de los profesionales de enfermería frente a la pandemia del Covid-19.

Método: Análisis teórico-reflexivo sustentado en estudios desde la perspectiva marxista, artículos científicos nacionales e internacionales y documentos oficiales de la Organización Mundial de la Salud y el Consejo Federal de Enfermería.

Resultados: El trabajo diario de los profesionales de enfermería ante la pandemia de Covid-19 presenta condiciones desfavorables en Brasil y en todo el mundo, con énfasis en el déficit de profesionales, sobrecarga de actividades, salarios bajos y equipos de protección personal a menudo insuficientes e inadecuados, condiciones que pueden conducir al agotamiento, la enfermedad y la muerte.

Conclusión: Este estudio puede contribuir a generar discusiones sobre la necesidad de mejorar las condiciones de trabajo de los profesionales de enfermería, especialmente en tiempos de pandemia y el impacto en la salud de estos profesionales. Palabras clave: Condiciones de trabajo. Impacto psicosocial. Infecciones por coronavirus. Enfermeras practicantes. 


\section{INTRODUCTION}

The transformations in the world of work in these first decades of the $21^{\text {st }}$ century originate from the structural crisis of capital and the process of productive restructuring that began in the 1970s and that "is characterized, among other aspects, by the proliferation of managerial policies aimed at flexibility and precarious conditions for hiring workers, in addition to the more intensified temporal and productive experience of the working hours ${ }^{\prime \prime(1: 1)}$.

This structural crisis of capital that involves and affects the system as a whole is due to the "new social and economic transformations brought about since the rise of the Taylorist-Fordist model, with its influx in the 1980s/1990s, with the weakening of the Fordist-Keynesianism system"(2:23207). These authors add that these transformations have had an impact on the lives and working conditions and health of workers who have their work capacity compromised by being subjected to precarious working conditions.

In the daily work of Nursing professionals there are unfavorable environments, poor working conditions, overload, intense pace, long hours, physical and psychological wear out, occupational stress, interpersonal conflicts, low remuneration, and professional devaluation ${ }^{(3-4)}$. During the pandemic, these conditions were enhanced and added to several other new factors that require attention from the Nursing categories on the exercise of their professions in current times, for prospective analyses of the health work they perform and protection of guarantees of their working conditions and of patient safety.

This pandemic emerged in December 2019 in the city of Wuhan/China, with the spread of a new coronavirus responsible for causing the Severe Acute Respiratory Syndrome 2 (SARS-CoV-2), and soon affected society globally ${ }^{(5)}$. In an emergency measure, the scientific community characterized the existence of the new etiological agent of the coronaviridae family, responsible for the disease of the new coronavirus, called Covid-19 (coronavirus disease 19) that, in the face of a fast pandemic spread, has already generated millions of cases and deaths worldwide due to its high transmissibility ${ }^{(5)}$.

According to officially recorded data, the spread of SARS-CoV-2 has so far infected 94,295,595 individuals in various countries around the world (01/16/2021), of which $2,018,174$ died. Brazil has recorded 8,393,492 cases and 208,246 deaths $^{(6)}$.

The sources used to support the theoretical course of this study were as follows: Marx and Engels $s^{(7-8)}$, among other authors, who address the process of productive restructuring and its repercussions on the workers' work processes.
From the epistemological perspective of historical and dialectical materialism, the production of ideas and consciousness is linked to the activity, material commerce and the language of real life men and women, and it is real men and women who produce their representations, in the way they were conditioned by a "determined development of their productive forces and the way of relations that corresponds to them, even including the broadest forms that

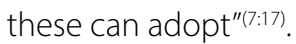

The Marxist epistemology makes it possible to understand the principle of totality, considering the multiple relationships that exist in the world of work and the objective links that involve historical events that express the challenges faced by the workers in the face of contradictions in the labor relations ${ }^{(7)}$.

Given the above, the following question arises: What are the working conditions of Nursing professionals in the face of the Covid-19 pandemic? In this sense, this study aimed to trigger a reflection on the current working conditions of Nursing professionals in facing this pandemic.

\section{METHOD}

A theoretical-reflective study, whose methodological question proposes to analyze the changes arising within the production of Nursing work, highlighting the context of the Covid-19 pandemic. The documents analyzed were obtained through national and international scientific articles, official documents from the World Health Organization (WHO) and the Federal Nursing Council, among others considered relevant. Data from the report entitled "State of the world's nursing 2020", prepared by the WHO, the International Council of Nurses and the worldwide campaign Nursing Now are presented.

Considering the Covid-19 pandemic that evidenced the performance of Nursing professionals, this study chose to focus on two thematic axes: "The deficit of Nursing professionals and Covid-19" and "The precarious working conditions, work overload in the Covid-19 pandemic, and the health of Nursing professionals". The analysis presented is supported by the Marxist epistemology that implies thinking about the multiple relationships that exist in this work context.

\section{Staffing of Nursing professionals and Covid-19}

The report prepared by the World Health Organization (WHO), the International Council of Nurses and the worldwide Nursing Now campaign, entitled "State of the world's nursing 2020", translated into Portuguese as "Situação 
da enfermagem no mundo 2020", had the participation of 191 countries and, based on data obtained from nearly $80 \%$ of the countries in the world on 15 indicators analyzed, presents convincing arguments that demonstrate the value of the Nursing team worldwide, and shows that this workforce as an occupational group has expanded with an increase of 4.7 million in total during the 2013-2018 period, representing nearly $59 \%$ of the health professionals ${ }^{(9)}$.

Among the 27.9 million Nursing professionals, 19.3 million (69\%) are nurses, 6.0 million (22\%) are nursing assistants and 2.6 million (9\%) were not classified in either of these two groups. However, despite this increase, the expansion is still disproportionate in relation to the accelerated pace of social, economic, environmental and epidemiological changes, as well as the different demands and needs of developed and developing countries, with respect to their growing population demand(9).

In relation to Brazil, the data indicate that Nursing professionals represent 2,119,620 (70.2\%) of the health personnel, of which 511,535 (24.12\%) are nurses and 1,608,085 (75.88\%) belong to other Nursing categories (Nursing Technicians, Nursing Assistants, Nursing Attendants and Midwives). Density is 101.4 Nursing professionals per 10,000 inhabitants, which indicates a value above the limit in comparison with other references ${ }^{(10)}$.

Nursing care in the country is mainly carried out by mid-level workers, whose workforce is quantitatively larger and less qualified. This relationship between short training and large offer of courses, among other facilitating factors, means that the acquisition of this workforce is always below its value, allowing, until then, a"reserve army", that is, a large mass or "overpopulation" of workers available to the employer and which helps regulate the wage leveling almost always below the work force that exercises the profession ${ }^{(8)}$. It thus constitutes an available reserve that belongs to capital in such an absolute manner, as a human material always ready to be explored and as if this system had created it on its own account ${ }^{(8)}$.

This national reality has an impact on the generation of value of the Nursing categories as a whole. The Professional Nurse, with higher intellectual qualification, requiring minimum studies of five years of academic training, in addition to an evident and expected escalation of continuing education for post-graduate courses, masters and doctorates due to the growing specialization branches of the profession, still receives the lowest employability and low working conditions.
The arrival of the pandemic behaved like a newly opened service branch, precipitating progressively and frantically over the old branches of the expanded market production. Suddenly, large masses of workforce were required, the main one being that of Nursing, which, if not available to be quickly allocated at work points, would bring about a big break in this scale of production and service ${ }^{(8)}$.

Therefore, it is not a peculiar curriculum in modern Brazilian Nursing, the generation of its value not being proportional to the growing demand for work or the improvement of the science of the profession, showing itself to be a working population that is still exploitable. The sudden and intermittent expansion of the demand for Nursing service in the face of Covid-19, with an overpopulation of workers available, now with even greater service overload and risks, among other points of devaluation, would only be different in the face of a scenario where the number of workers does not exceed the ratio of increased production.

As a counterpoint to the relationship of Nursing professionals per number of inhabitants in Brazil, the employers hardly respect the adequate staffing of the team in relation to its complexity level, making possible a deficit of purposeful professionals, due to the behavior where overloading the worker is sustainable at the service and often even allowing for the invasion of exclusive activities of the Professional Nurse by other professions, nullifying the due requirements of the bodies that govern Nursing and demonstrating the arbitrary conformation of the value of this professional's workforce.

We can infer the various consequences for the population when we observe that this value adjustment does not occur, especially the challenges faced in the current pandemic. Epidemiological information continues to indicate an increase in Covid-19, with a shortage of hospital beds, especially those in Intensive Care Units (ICUs), respirators in hospitals, as well as the number of health and nursing professionals in the world and in the Brazilian states.

This large historical demand for workload, which has increased even further with the pandemic, makes health professionals within ill-staffed teams assist patients according to the clinical priority or to their prognosis, that is, often needing to make bioethically questionable decisions about which patient will receive care, often to determine who will have intensive respiratory support and surveillance, given the insufficient capacity to provide assistance to all due to the small qualitative and quantitative Nursing-patient ratio in high-complexity services. 
In view of the complex scenario, the consumption of the Nursing workforce is even higher, the rapid renewal of the generation of workers is expected within these conditions; however, as an aggravation of an already chronic condition, a new decree was enacted in Brazil allowing the voluntary hiring of Nursing students in the fifth and final year of training, with a certain appeal of social duty and without due exhaustion of the possibility of hiring nurses duly qualified to manage this scenario.

Nursing staffing was already inadequate in the national territory, now, in view of the increased level of complexity of the patients in the pandemic context, added to the increase in absenteeism and turnover of professionals, this reality receives greater impediments ${ }^{(11)}$. The increase in Nursing turnover and absenteeism rates are correlated in a study with unfavorable outcomes, such as, for example, the incidence indicators of unplanned extubation in intensive respiratory therapy, in addition to the incidence of loss of nasogastric and nasoenteral tubes, the incidence of skin lesions, and the incidence of loss of central venous catheter ${ }^{(11)}$

In the fast need of workers to provide Nursing care in the institutions, the recruitment and selection process takes measures to increase hiring without adequate integration to institutional routines and protocols, or permanent education, exposing the professionals to a greater risk of negative consequences in their work practice and of causes of risk events/circumstances with potential harm to the patient. The hiring format also becomes more flexible, bringing temporary contracts and day/shift pay as a common practice in the current scenario, as well as new labor contracts that agree upon overtime hours not financially remunerated, being paid by the employer in hour bank format, with breaks foreseen for distant periods, even semesters, after the days worked.

The visualization of this context allows us to understand the elements that make up Nursing, where the value of its workforce is not conditioned by the variables of length of the workday, work intensity or by the productive workforce in the face of the current pandemic, but rather becoming even more precarious, entering into the reckoning of this low generation of value, both the historical elements of the cultural development of the profession and society, as well as the contradictory exploratory power of the social use value of their work, even greater in the face of the new production scenario(8).

In fact, from this point of view, there is an evident need for the Nursing working class to fight, for an extremely priority position, in measures to avoid underinvestment and chronic professional under-staffing, since the value of its workforce is the value of its means of subsistence, as well as, it is expected to guarantee its maintenance in the face of variables in the productive scenario and to ensure its reproduction for those who in the future will be entering the same market ${ }^{(7)}$.

\section{The precarious working conditions, work overload in the Covid-19 pandemic, and the health of Nursing professionals}

The social value of Nursing has gained some attention in addition to the class convictions, formulated during this period in the face of concrete material conditions experienced at work and in life. To a large extent, social values stem from economic values; however, it was at this time of collective health crisis that the contradictions of the negative correlation of labor factors that coexist with the extreme responsibility required from the Nursing practice proved to generate critical social formulations, with greater spaces for discussion and repercussion in the media, but with no evident impediment to the continuation of weakened employment contracts, low wages and an extremely high workload(8).

If this well-known scenario already existed, where the Nursing workforce develops and remains in conditions below its value, now in reaction to the pandemic crisis, it is indispensable to look at occupational health, in its psychosocial, physical, and ergonomic dimensions ${ }^{(12)}$. Illness at work can also be characterized as Burnout syndrome, a phenomenon attributed to highly stressful work environments, reflecting on personal exhaustion and decreased professional achievement, which can result in ineffective Nursing care capable of causing iatrogenesis ${ }^{(12)}$.

With the spread of Covid-19, the health services have become overloaded and the professionals are dealing with even greater stressors on a daily basis and face the intense increase in risks to their own health as previously seen in modern Nursing science. Although research on the effects of the pandemic on the health and well-being of the Nursing team is still sparse, in summary, the existing studies bring as factors contributing to professional exhaustion the fear of infection for themselves and for family members and friends, the fear of the relatively unknown effects of the disease, the levels of work-related stress and the extremely long working hours, requiring more bedside time due to increased complexity, the lack of adequate PPE, and the constant tension of informing family members that they will not be able to be with the patients within the services, as well as giving emotional support to these patients in isolation ${ }^{(13)}$. 
As hospitals have reached their maximum capacity, supplies, such as PPE, which are essential for protection and indispensable to prevent contagion, have become scarce as have several other articles. Given the challenge of supply and demand for this equipment in the domestic and foreign markets and even the predatory conduct of some countries to absorb this supply in the world market, Brazilian Nursing experiences potential biological risks ${ }^{(13)}$.

It is also noteworthy that the use of these protective articles, previously punctual, is now being used continuously, with uncertainty about the real biosafety of the equipment in this new extensive use format, as well as difficulties with breathing, communication and other physiological needs among professionals, in addition to also causing related pressure injuries.

The fact of providing assistance in unprecedented public health situations such as the current one and regarding a pathophysiology that has not yet been fully explained, is sometimes consistent with a Nursing practice that is not based on evidence due to the still incipient advance of science on this emerging disease and the lack of a "gold standard" consensus to support the management of the various variables that may exist within this clinical condition.

Making use of the practice of empiricism can also be a major additional stressor for the professional in coping with adversities, whether they are related to aspects of care management, pharmacotherapeutic of the patient or even the prescription of Nursing care, often implying anxiety and insecurity. To meet this need, the professionals still need to be constantly updated on new scientific information.

In highlight, it is observed that frequent exposure to direct care of patients with the disease has increased the illness of professionals due to the high transmissibility of the new coronavirus, as well as death ${ }^{(13)}$. Data obtained from the Federal Nursing Council on January 16 ${ }^{\text {th }}, 2021$ indicate that up to that date, 46,775 Covid- 19 cases in Nursing professionals were recorded in Brazil, of which 519 died, with a lethality rate of $1.94 \%^{(14)}$.

In this way, it is possible to understand that the larger the productive force of work, the greater the pressure of the workers on their occupation means, and the more precarious, therefore, the sale of their own force with a view to increasing the wealth of others or the self-appreciation of capital, the lower the quality of health care that will be provided to the population experiencing this critical scenario ${ }^{(8)}$. At the same time that the world population requires demanding care and Nursing professionals carry out this care full-time, acting both in measures to prevent the spread of the disease and in health promotion, Nursing diagnoses, treatment, recovery and rehabilitation of symptomatic or confirmed patients for Covid-19, in addition to all follow-up and support, both for them and their families, even so, what is observed are low guarantees of adequate working conditions being reactively extended now to the pandemic scenario.

There is still a context of uncertainties, but it is learned that the pandemic did not distinguish in relation to the maturity and responsiveness of the care models and the staffing of Nursing professionals, as well as whether their working conditions are or not adequate, its price of the labor force being or not equivalent to its labor value, and consequently there were several impacts on the profession's work practice (Figure 1).

Despite this, it is not the first time that Nursing has dealt with a pathological agent disseminated worldwide, nor in a scenario of economic disorganization and lack of equipment and materials, or even affected by market interests that do not favor it. The previous epidemics in world history bear some similarities in the competence of Nursing to face the situation, as well as the representation of Florence Nightingale during the Crimean War, or in different other contexts in which the profession has already shown itself essentially able to build new knowledge and generate results that impact the defense of population health.

In general, Nursing professionals are at the forefront of the professions that dealt very closely with the control of highly infectious diseases. In this history, it can be said that the behavior of the professional category is known to meet the need for an increased workforce and demonstrate willingness to assume the existing risks as part of its role and social responsibility, including those that affect the very health of the professional.

In this discussion axis, it is important to highlight that the history of Nursing is full of collective strength involving politicization of care, where nurses practice a form of clinical militancy, mainly motivated by issues of social justice in relation to the patient's well-being, processed along with demands for better working conditions. Crucially, these stories in several international contexts guaranteed improvements in the Nursing work relationships and in the resources allocated for care, often at the same time ${ }^{(15)}$. 


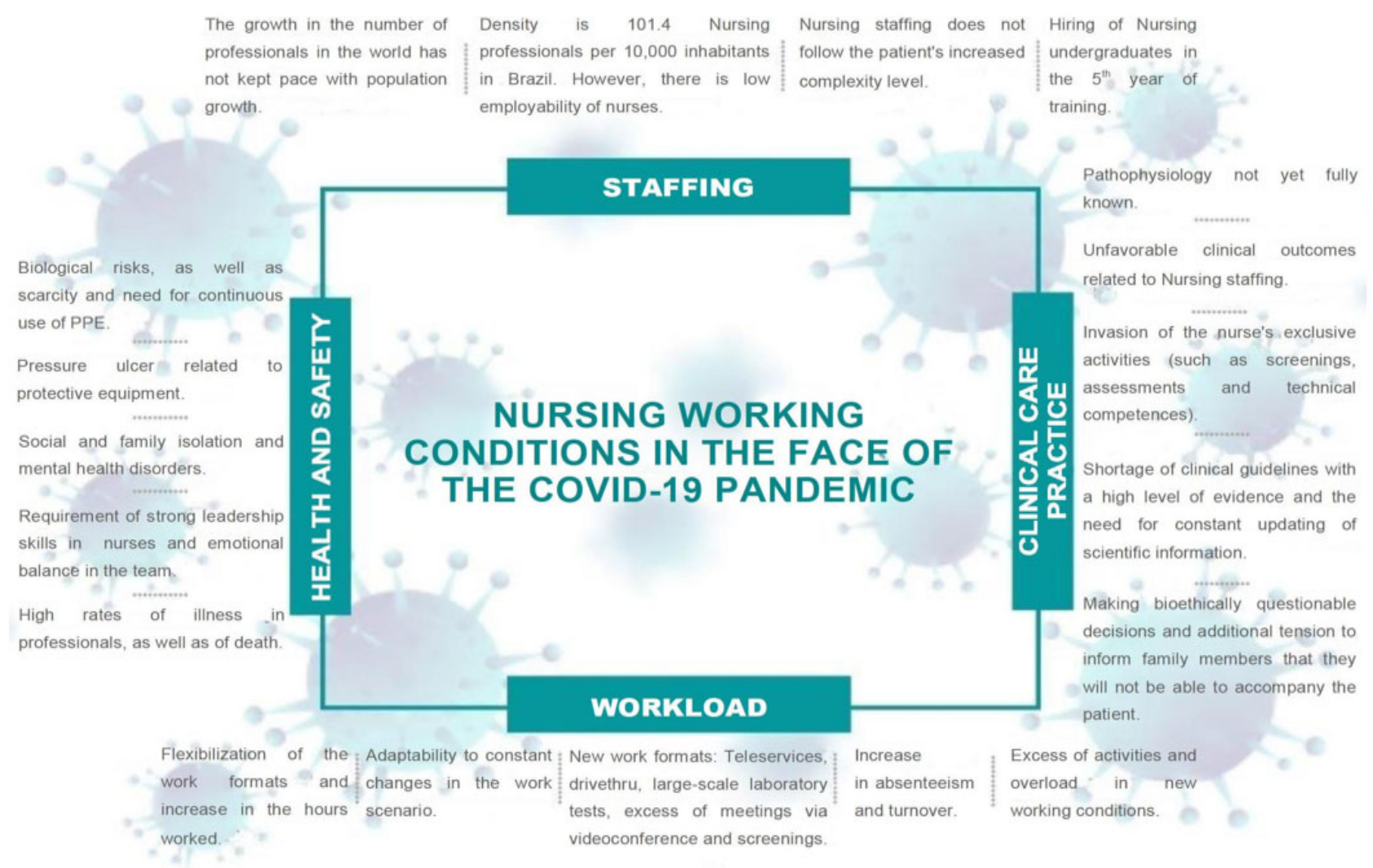

Figure 1 - Characterization of the Nursing working conditions in the face of the Covid-19 pandemic

\section{CONCLUSION}

The challenges of work overload, under-staffing of teams and other challenging facets already known to the Nursing profession, added new complexity to the field of work with the unthinkable and unprecedented increase in the lack of protective equipment, high illness and death rates in the professionals, exercise of the clinical practice in the face of an unknown pathophysiology, and the excess of complex care demand in the face of high absenteeism and staff turnover, in addition to many other factors that also contribute to professional exhaustion, health risks and low quality of care.

On the one hand, it can be thought that the relationship of complacency of the profession with the needs of collective health is used at this time to promote further overload and devaluation of the category, to the extent that there is a precariousness of working conditions and a consequent disruptive action with care quality.

It is desirable for the moment that Nursing conceives and embraces a professional identity that is simultaneously politically engaged, starting from reflecting and looking at all aspects exposed within this study, in order to recognize how collectively the category has dealt with the pandemic scenario and to seek the just significant expression of the value of its work.

With the worldwide Nursing Now 2020 Campaign, the visibility of the performance of Nursing professionals in the face of the Covid-19 pandemic and the reaffirmation that these professionals need and must be valued, society is expected to review the stereotypes attributed to the profession and understand the importance and essentiality of these health care professionals for global health, which, in addition to applause, need recognition and decent working conditions that include adequate staffing, permanent education, fair wages, favorable work environments (with a place and environment for rest) and reducing the workload to 30 hours a week.

In addition to that, the profession itself has this self-awareness disseminated and demands its ideal working conditions, so that it can advance in this scenario, with focus and safety on the patient, with attention to the flows and continuity of care, bringing Nursing knowledge, research and innovation to this scenario, studying the particularities of Covid-19, also 
advancing these studies within our specialties of clinical-surgical, pediatric, obstetric, intensive care, dermatological, gerontological and many more.

It can be said that Nursing has never before received such generalized stressors to the professions of this category in such intensity, with regard to the need to demonstrate efficiency, agility and adaptation. Furthermore, it is still not possible to understand how long this scenario will be prolonged or hindered. Therefore, this study can contribute to raising discussions about the need for improvements in the working conditions of Nursing professionals in pandemic times and the impact on the health of these professionals, with its limitation being not having advanced the quantitative analysis in search of identifying the opportunities developed for an intervention in the scenario, requiring a new study focus.

\section{REFERENCES}

1. Almeida FMRS, Lima LA. Qualidade de vida no trabalho e saúde do trabalhador: considerações metodológicas. EEDIC. 2017 [cited 2020 Jun 10];4(1):1-6. Available from: http://publicacoesacademicas.unicatolicaquixada.edu.br/ index.php/eedic/article/view/2686

2. Silva JPC, Ferreira LS, Almeida BLF. Os impactos das atuais condições de trabalho na saúde do trabalhador: 0 trabalho sob a nova organização e o adoecimento dos trabalhadores e das trabalhadoras atendidos no Cerest/JP. Braz I Develop. 2019 [cited 2020 Jul 10];5(11):23206-20. Available from: https://www. brazilianjournals.com/index.php/BRJD/article/view/4341

3. Miranda FMA, Santana LL, Pizzolato AC, Saquis LMM. Condições de trabalho e 0 impacto na saúde dos profissionais de enfermagem frente a Covid-19. Cogitare Enferm. 2020;25:e72702. doi: https://doi.org/10.5380/ce.v25i0.72702

4. Santana LL. Riscos psicossociais e saúde mental em ambiente hospitalar: com a voz 0 trabalhador [tese]. Curitiba (PR): Programa de Pós-graduação em Enfermagem, Universidade Federal do Paraná; 2018 [cited 2020 Jun 25]. Available from: https://www.prppg.ufpr.br/siga/visitante/trabalhoConclusaoWs?idpessoal $=14957 \&$ idprograma $=40001016045$ P7\&anobase $=2018 \& i d t c=79$
5. Wei X-S, Wang X-R, Zhang J-C, Yang W-B, Ma W-L, Yang B-H, et al. A cluster of health care workers with Covid-19 pneumonia caused by SARS-CoV-2. J Microbiol Immunol Infect. Forthcoming 2020. doi: https://doi.org/10.1016/j. jmii.2020.04.013

6. World Health Organization (CH). Coronavirus disease (Covid-19): situation report - 188. Washington (DC): WHO; 2020 [cited 2020 Jul 20]. Available from: $\quad$ https://apps.who.int/iris/bitstream/handle/10665/333576/ nCoVsitrep26Jul2020-eng.pdf? sequence $=1 \&$ isAllowed =y

7. Mark K, Engels F. A ideologia alemã. 2. ed. São Paulo: Martins Fontes; 2001.

8. Mark K. 0 capital crítica da economia política: Livro I o processo de produção do capital. São Paulo: Boitempo; 2013

9. World Health Organization (CH). State of the world's nursing 2020: Brazil [Internet]. Washington (DC): WHO; 2020 [cited 30 Jul 27]. Available from: https://apps.who.int/nhwaportal/Sown/Files?name=BRA

10. Legido-Quigley H, Mateos-García JT, Campos VR, Gea-Sánchez M, Muntaner C, McKee M. The resilience of the Spanish health system against the Covid-19 pandemic. Lancet Public Health. 2020;5(5):e251-2. doi: https://doi. org/10.1016/S2468-2667(20)30060-8

11. Monteiro LM, Spiri WC. Quality indicators and workload of an integrative review in nursing. Rev Min Enferm. 2016;20:e936. doi: https://doi. org/10.5935/1415-2762.20160006

12. Arnetz JE, Goetz CM, Arnetz BB, Arble E. Nurse reports of stressful situations during the Covid-19 pandemic: qualitative analysis of survey responses. Int J Environ Res Public Health. 2020;17(21):8126. doi: https://doi.org/10.3390/ ijerph17218126

13. Zhang H, Ye Z, Tang L, Zou P, Du Z, Shao J, et al. Anxiety symptoms and burnout among Chinese medical staff of intensive care unit: the moderating effect of social support. BMC Psychiatry. 2020;20:197. doi: https://doi.org/10.1186/ s12888-020-02603-2

14. Conselho Federal de Enfermagem [BR]. Observatório da enfermagem [Internet]. Brasília (DF): COFEN; c2020- [updated 2020 Dec 12, cited 2020 Jul 27]. Available from: http://observatoriodaenfermagem.cofen.gov.br/

15. Mckeown M. Love and resistance: re-inventing radical nurses in everyday struggles. J Clin Nurs. 2019;29(1):1023-5. doi: https://doi.org/10.1111/ jocn. 15084 
Backes MTS, Higashi GDC, Damiani PR, Mendes JS, Sampaio LS, Soares GL

\section{- Acknowledgments:}

To CAPES for the financial aid for the Graduate Program in Nursing of the UFSC.

\section{- Authorship contribution:}

Conceptualization - Marli Terezinha Stein Backes; Giovana Dorneles Callegaro Higashi; Pattrícia da Rosa Damiani; Janifer Souza Mendes; Lucimar de Souza Sampaio; Gustavo Lopes Soares.

Data curation - Marli Terezinha Stein Backes; Pattrícia da Rosa Damiani; Janifer Souza Mendes; Lucimar de Souza Sampaio; Gustavo Lopes Soares.

Investigation - Marli Terezinha Stein Backes; Pattrícia da Rosa Damiani; Janifer Souza Mendes; Lucimar de Souza Sampaio; Gustavo Lopes Soares.

Methodology - Marli Terezinha Stein Backes; Pattrícia da Rosa Damiani; Gustavo Lopes Soares.

Project management - Marli Terezinha Stein Backes; Pattrícia da Rosa Damiani.

Writing - Original draft - Marli Terezinha Stein Backes; Giovana Dorneles Callegaro Higashi; Pattrícia da Rosa Damiani; Janifer Souza Mendes; Lucimar de Souza Sampaio.

Writing - Review and editing - Marli Terezinha Stein Backes; Pattrícia da Rosa Damiani; Gustavo Lopes

Soares.

\section{- Corresponding author:}

Pattrícia da Rosa Damiani

Email: pattriciadamiani@outlook.com

\section{Associate editor:}

Dagmar Elaine Kaiser

Editor-in-chief:

Approved: 01.27.2021
Maria da Graça Oliveira Crossetti 